Carvalho, Clara, "Visual instruments in social science research" in Readings in Methodology: African Perspectives. Edited by Jean-Bernard Ouédraogo \& Carlos Cardoso. Dakar, CODESRIA, 2011, 272 p., ISBN: 978-2-86978-483-3, pag. 163-173

http://www.codesria.org/IMG/pdf/10-Carvalho_Readings_in_Methodology.pdf

\title{
10
}

\section{Audiovisual Instruments in Ethnographic Research}

\section{Clara Carvalho}

\section{Introduction}

In 1973, the most renowned researchers in Visual Anthropology met at the ninth International Congress of Anthropology and Sociology to discuss the role of film and photography in ethnographic research and to systematize the almost century-old experiences of bringing together description, ethnography, photography and film. Opening the meeting, Dean Margaret Mead enthusiastically defended the use of audiovisual instruments in research. Considering that Anthropology explicitly or implicitly accepted the responsibility of 'preserving' the descriptions of disappearing cultural habits, Mead prescribed the need for an 'urgent anthropology' that used photographs and films as supporting research means. She endorsed the view that the camera should be used as a research instrument as well as a means of disseminating a study, conjuring concerns with the film's stylistic and aesthetic qualities while stressing its documental value. In her own terms, Anthropology should maximize the potentialities of the audiovisual media within its reach instead of being merely a 'science of words' (Mead 1995).

Mead's point of view was quickly criticized within a disciplinary field concerned with problems of interpretation of the subject, deep ethnographic description, and the post-colonial criticism of the role of the observer as a political subject and actor. The Danish anthropologist Kirsten Hastrup echoed these concerns when she denounced Mead's positivist conception of the discipline. For Hastrup, the defence of an urgent anthropology could only be defended within the perspective of humanity as a 'human zoo', a collection of immutable and a-historical subjects and social formations that were better described, in their immobility, by pictures. On the contrary, Hastrup states that Anthropology is a form of knowledge made up of subjects engaged in an active relationship ('observer' and 'subject'), historically situated and politically conscious. This interrelationship may 
only be expressed by the textual 'deep description'. Furthermore, the creation of the visual archives of humanity, as defended by Mead, would be hostage to a view of the disciplinary field as engaged in preserving cultural habits that have become obsolete, refusing to recognize the historicity of the groups described. And she continues,

Anthropologists - as people - belong to the class of things that are subject to their understanding. Whether equipped with notebooks or cameras, ethnographers always define reality at the moment they discover it. It is this continuity between subject and object which marks the construction of ethnography and which must be taken into consideration when assessing the difference between visual and textual forms of authority (Hastrup 1992:10).

Visual Anthropology falls between these two opposite positions. It arises from a broad field of studies, which includes both local cultural manifestations such as visual creation, dance, aesthetics, architecture, as well as research records through audiovisual media, their edition and public presentation. Being an innovative mean of research and implying a different approach to the field, Visual Anthropology challenged the discipline itself. In this text, I will be concentrating on its use as a means of research and as a form of presenting a research project, ignoring the entire field of interpreting the material and visual manifestations of a defined group. The artificial distinction, made in this paper between the use of film (in film, video or digital format) and photography, is justified by their distinct histories within the disciplinary practice. My intention was not to carry out a systematic study on these media within the discipline but to discuss their potentialities and limitations. Finally, I will look at the use of complex digital products such as CDROMs and the Internet, which encourage new practices and new means of research diffusion.

\section{The Use of Films in Anthropological Research}

Both Anthropology as Photography and Cinema are forms of knowledge that arose from the industrial and academic development of the late nineteenth century and enlarged within the urgent need to classify, typologize and integrate human diversity into hegemonic political projects of the modern colonial period. In this sense, we may consider that the first films are ethnographic (La Sortie des Usines, Le Petit Déjeuner du Bébé by the Lumière brothers or the chrono-photographs of Félix-Louis Regnault), in the same way as the first systematic research in Anthropology resorted to the use of audiovisual instruments (such as the expedition to the Torres Strait of 1898, led by Alfred Cort Haddon). Currently, ethno-sociological documentaries, which have drawn closer to the language used in fiction movies and in television documentaries, mark our vision of ethnographic films. The work of Jean Rouch, French cineaste and anthropologist, author of the most innovative work in the field of ethnographic films, is in itself the best definition of this genre. Rouch, who anticipated and experimented within the 
possibilities of ethno-sociological documentaries, considered Robert Flaherty and Dziga Vertov as the 'totemic ancestors' of Visual Anthropology. They certainly continue to be seen as the most prominent benchmarks of socio-anthropological documentaries. Robert Flaherty, a mining prospector operating in Hudson Bay, presented to the world the famous Nanook of the North in 1921, the delightful saga of the Inuit Nanook and his family in the Great North. Directed with the assistance of the people in the film, who intervened in the choice of the topic and the edited sequences, this narrative appears in the form of a narrative drawn between fiction and reality, the joint creation by a moviemaker and the people filmed. The arduous struggle of the Inuit to survive in the Great North is recreated in this enchanting work, where the actors involved chose to portray hunting and fishing techniques that were no longer used at the time so that the film could serve as a memorial of techniques dating back several millenniums. The film is also worth watching for the expressive humanity revealed in the beautiful smile of Nanook, which led millions of spectators to identify themselves with this faraway hunter from the Great North, who died shortly after the beginning of this work. Moreover, this work is the product of an ethnological pre-survey and was directed at a form of human essence underlying the acts, representing Man's fight against Nature. In this film, we acknowledge the questions which Anthropology - and even Visual Anthropology - only raised seven decades later. How does one film others? What right do we have to manipulate and exhibit their image? As an image can be perceived by the senses, how does one involve the people depicted in the film in its creation? What relationship should be established with reality in a documentary film? Nanook of the North deals with these issues without losing sight of the fact that a film, as a form of information and entertainment, should maintain a recreational nature and should bring about an aesthetic emotion. The identification, the play on the emotions and on the senses made possible by the mimetic nature of the images, the narrative creation between those depicted in the film and the producers, have demarcated since then a style of ethnographic film that continues to be evoked to date.

Another great lesson from Visual Anthropology' 'totemic ancestors' comes from Dziga Vertov, Soviet producer and contemporary of Flaherty, whose cinematographic and essayistic work forces us to reflect on the manipulated character of every mimetic work. This reveals the true paradox of cinema which applies to Visual Anthropology, as Dziga Vertov puts it:

(Cinema) is, in fact, the product of the double work of men to organize and understand their existence and of the observer who puts together the images of this representation to take apart his own dynamic. Reality is neither the object shown, nor the constitution of the demonstration; it lies in the constant passage from one to the other during which the cineaste appears successively in the situation which he himself defined' (Vertov quoted in Piault 1991:149). 
Dziga Vertov's work leads the spectator to reflect on the interpretation of realities and knowledge that the camera forces us to make. In a certain sense, he anticipates and responds to the critiques literary critic James Clifford addressed to the ethnographic texts in 1986, a summary of the reflexive critique of the eighties and nineties. Clifford stated that all ethnographic text is interpretive and expresses constraint of an academic, political, historical and even stylistic order. He was echoing Vertov when the latter affirmed the built-up character of the film, which only exists as a construction and interpretation of reality. His effort to create an interpretive film comes close to the thick description of Clifford Geertz, a description/ interpretation that contributes to a multilevel understanding of social interaction. Between the notion of the film as an interpretive language in Vertov's work and Flaherty's fictional experience, the key elements of ethnographic cinema are drawn, affirming this media as a privileged means of presenting human experiences.

The potentialities of this media were not immediately perceived from within the discipline. The use of film and of photography in Anthropology was for a long time a secondary act to the discipline itself, despite always having its fans, defenders and practitioners. Between the two wars the world witnessed the development of documentary cinema and besides the works of Robert Flaherty and Dziga Vertov, previously mentioned, the movies by Jean Vigo, Joris Ivens, Jean Epstein and John Grierson are noteworthy. Also in Anthropology, trained academic were introducing cinematographic records in their research. In Mali, Marcel Griaule filmed Au pays des Dogon in 1935 and Sous les Masques Noires in 1938; Franz Boas filmed among the Kwakiutl in Canada, while Margaret Mead and Gregory Bateson used their camera and video camera in their research projects between Bali and New Guinea, taking 25,000 photos and shooting 6,000 meters of film as an example of their theories on non-verbal behaviour, comparing different cultures. For these authors, the camera was seen as another research instrument, whose potentialities for recording information were used independently of the final construction of an exhibition film.

After World War II, technological developments made it possible to address new potentialities in ethnographic film. Cameras become lighter with the dissemination of $16 \mathrm{~mm}$ films, which led Jean Rouch to film without a tripod, with a camera on his shoulder, in close collaboration with the people being filmed. The main innovation lies, however, in the introduction of synchronic sound and light cameras in 1960, which made it possible to interview the people being filmed and to introduce their voice. Authors such as Jean Rouch invented 'cinéma vérité, later dubbed 'direct cinema', and the subtle boundaries between ethnosociological films and fiction movies were softened. This was also the time of the emergence of the first centres dedicated to the production of ethnographic films in the academic arena. This approach promoted a close collaboration between anthropologists and movie directors, skills often present in the same person: one of the exponents of this tendency is represented by the work of Timothy Asch, Robert Gardner and Jay Ruby. In the sixties, several television chains were interested in this production and joint productions between academic and television 
producers gave rise to several series disclosing ethnographic research. The best known is the Granada Centre in the University of Manchester, UK, where media series such as Disappearing World were produced. Furthermore, we witnessed the development of documentaries with typological concerns, centred on ethnomusicology, ethnolinguistics, technology and even rituals, as seen in Mead and Veuve's examples. This approach is also adopted by the IWF (Institut für den Wissenschaftlichen Film), founded in 1956 in Göttingen, Germany, which proclaims the superiority of films as a method for anthropological documentation and analysis. The IWF created the Encyclopaedia Cinematographica (EC), attempting to produce as many short films as possible (preference unedited sequences) on 'minimum units of human behavior' such as techniques and rituals, supposedly able to be compared with each other. These short films included written information such as the location of the group, date, or specific ethnographic information, but should not contain outside comments (Loizos 1994, 195-196). However, criticism of this policy of affective, political and interpretative stripping brought about a change of strategy both within the IWF and Visual Anthropology in general. Currently, ethnographic films have come very close to documental cinema and are both interpretative and thought-provoking. The ethno-sociological movie expresses both the restlessness of its author and the political conscious objectives of the people involved and filmed. It may even assume the media character as a means of political action, as expressed by the impact of films such as The Kayapo out of the Forest, by Michael Beckham and Terence Turner in 1989.

The designation ethnographic film indicates a wide variety of visual documents within the reach of both researchers and professional moviemakers. Its potential and dissemination were further enhanced by the dissemination of small digital cameras and the ease with which digital images can be worked on. The current low cost and high durability of digital cameras and recording media make it possible to use these machines as an effective support to every research. The socalled 'notebook cameras' have revealed new recording possibilities. Cameras can be used to capture research records, surveys of space or material culture, recording interviews or even staged activities such as technologies, dances, rituals and ceremonies. Both the researchers and the people who were filmed can work these recorded materials on. This allows sharing representations and even interpretations between the people involved, irrespective of how the records are used afterwards. The camera creates records that are mimetically thick and emotionally more powerful than traditional written annotations. Furthermore, movies use a language that is easier to share and disseminate, where the voice of the players and their collaboration in the ethnographic construction is obvious. Films are more easily shared than written annotations, and this potential enables a new dialogue between researchers and the people they work within their projects and who are not any longer considered as mere 'informers'. Finally, as mentioned bellow, these films may be shared via the Internet, providing research with greater transparency. 


\section{Photography and Anthropology}

The intrinsic characteristics of photographic images deserve to be seen from a particular perspective. Still image is, before all else, a mimetic object. As an object it can be manipulated, collected, reinterpreted. As a mimetic body, as Susan Sontag reminds us, it is particularly effective in its apparent relationship of loyalty with reality. This relationship leads to a deceptive copy of reality, as it is based on the false premise that photographs are snapshots that do not take into account their manipulation, the setting, the choice of the moment, the point of view expressed. Sontag goes on to say:

To photograph is to appropriate the thing photographed. It means putting oneself into a certain relation to the world that feels like knowledge - and, therefore, like power (Sontag 1983:16).

Even if the photograph does not steal the soul, it manipulates an image and a self-representation, interfering with the fundamental rights of all human beings.

These characteristics - the creation of a manipulatable object with mimetic capacity and a power symbol - are present in all anthropological photographic collections since the nineteenth century. At the time, photography was used within the discipline as a form of objectively recording cultural and physical differences. An example of this is Alfred Cort Haddon's work, as mentioned above. Collections of pictures of submissive populations appeared in American and European museums in an exhibition on human diversity and of the technical superiority and power of the western photographers. Notice, however, that manipulating mimetic devices in order to create new symbols of power was a common way of experiencing the difference of social universes apparently irreducible in their cultural expression, as analysed by Michael Taussig in his inspiring work on the American Indians Cuna, Mimesis and Alterity. It is once again Sontag who brings to our attention the violent character of the act of photographing in her famous definition of photography as a firearm:

To photograph people is to violate them, by seeing them as they never see themselves, by having knowledge of them that they can never have; it turns people into objects that can be symbolically possessed. Just as a camera is a sublimation of the gun, to photograph someone is a subliminal murder (Sontag 1983:28).

This remark by the author has an obvious application in the construction of the first ethnographic picture collections that reflected the obviously manipulative and ideological construction allowed by the unshared image (Edwards 1992, Landau 2002, Ryan 1997).

Photography currently has different uses in ethnographic research. In the first place, it continues to be a vital instrument in the constitution of typologies, inventories, recording of cultural material, description and spaces and of the relation 
between people and space, studies in proxemics, as defended by John Collier (1996). This media was also extensively used by authors Margaret Mead and Gregory Bateson who defended its 'scientific and realistic' capacities (Pink 2001:49). Furthermore, photography became a key element within the reflexive criticism of the eighties and nineties. The picture of Stephen Tyler on the cover of the iconic volume Writing Culture (1986) is the best example of this concern with the role of the researcher in the research process. Picturing the 'field' experience was seen as an illustration of the description of inter-subjective processes of the construction of knowledge within the research project.

Anthropologists also pondered on the social use of photography, influenced by the cultural studies. Photography is a form of representation, observing social rules significant in it. In the course of the work of Pierre Bourdieu, ethnographers studied family albums, considering photographs as a social institution that contributes to commemorate particular moments in the lives of the group. By analyzing the events pictured, the layout of the photographs in the album and their manipulation, researchers were able to identify their role in the creation of the group self-representation, as exemplified in works by Erno Kunt and Marianne Hirsch. Currently, new research has emerged on the construction of visual cultures, the local interpretation of iconic elements and the meaning of specific iconographies. Photography as a practice of representation is expressed in both social interaction and symbolic constructions, two of the key elements social research is addressing.

Even within the research process itself, photography can be used as a means of recording and exchanging information, ideas and representational practices. Both recording research moments, namely those which express the relationship with the people involved, and the act of giving back pictures to the people photographed, are means normally used to mark the relationship that was built up, as well as a form of retribution within the field research. However, photography can also be used to speak of self-representation practices, especially when the people pictured are involved in the construction of the photograph. Its classic use as a form of gathering elements (of material culture or events) is enriched if it is commented on by other members of the research team. It is also an effective means of giving rise to research, namely asking for clarifications on the people photographed or discussing the representations. Furthermore, it can be used as a subterfuge to understand events not witnessed by the researcher or which the latter does not understand. Above all, photography is a powerful means of building up relationships during the micro-focused research that characterizes Anthropology. The exchange of photographs, the act of offering them as a gift, the joint construction of photographic representations are invaluable means of sharing and building up a relationship while the research is being carried out (Pink 2001). 


\section{New Technologies}

The use of CD-ROMs, web pages and even blogs has raised new research possibilities especially related to the dissemination of the research products. These were announced by the dissemination of the CD-ROM and of hypertext, a means of expression that made it possible to combine different types of materials, such as textual production, films, photographs or other iconographic sources, sound, including the voice of interviewees during the research process. These characteristics transform hypertext into a medium that is particularly adjusted to the diversity of ethnographic research, where there are countless meaningful elements. By including the image and voice of the people who took part in the research, the latter are given the role of co-authors of the final product, recognizing their own voice and differentiating it from that of the researcher. The identification of the various media and of the different texts makes it possible to separate the analytical interpretation from the description or even from the data gathered (Sperber 1982). This medium responds to the questions put forward by Margaret Mead and Kirsten Hastrup that were mentioned in the beginning of the text. This new medium includes the theoretical explanation of the text, which Hastrup associates with the density of written ethnography, enriching it with the multiple possibilities of the audiovisual surveys extolled by Mead.

Hypertext also calls for non-linear reading and a deeper and more active involvement of the reader, who is free to choose the materials presented on which to construct his own representation. As such, it leads to a less directive approach than the written text, but of a greater organizational complexity. Authors such as José Silva Ribeiro and Sérgio Bairon, or Rod Coover, have demonstrated the potentialities of this means of research diffusion, with particularly appealing results.

The characteristics of the CD-ROM were updated by the dissemination of web pages. Like CD-ROMs, web pages are characterized by the diversity of means and by the non-linear aspect of their presentation. Added to this is the possibility of the site being shared, commented on or even changed by a large number of readers in completely different locations. Anthropology, which Clifford accused of limiting itself to the academic environment, finds here a freer form of diffusion that is easier to read by the public in general and by interested parties in particular. Experiments worth mentioning are those conducted by the University of Kent (UK) on the sharing of information, particularly the Mandilla project headed by David Zeitlyn (available at http://lucy.ukc.ac.uk/dz/) or the work of Akos Ostor and Linda Fruzzetti in India. The possibilities of sharing information are endless, making it possible to set up interactive blogs and Internet sites. Images are an essential part of these media, where photographs and filmed sequences are thrown into relief. When the presentation is based on multiple texts, the filmed sequences are generally not very complex and it is easy to add new research data such as interview extracts or short surveys. Photographs are particularly suitable 
to this medium and may be used in any of the versions referred to above. The researcher must, however, respect the ethical principles of sharing images and other representations, involving the people photographed in this presentation of the research. The representational, interactive and sharing potential of the Internet has brought about a new form of diffusion for ethno-sociological research, decisively distancing Anthropology from the 'science of words' ascribed to it by Margaret Mead.

\section{Bibliography}

Banks, Marcus \& Howard Morphy (ed.), 1999 (1997), Retbinking Visual Anthropology, New Haven: Yale University Press.

Clifford, James, and Marcus, George (ed.), 1986, Writing Culture. The Poetics and Politics of Ethnography, Berkeley: California University Press.

Coleman, A. D., 1998, Depth of Field: essays on photography, mass media and lens, Albuquerque: University of New Mexico Press.

Collier, John, Jr.; Collier, Malcolm (postface by Edward T. Hall), 1996 (1986), Visual Anthropology: Photography as a Research Method (Revised and Expanded Edition), Albuquerque: University of New Mexico Press.

Coover, Rod, 2003, Cultures in Webs CD-Rom, Watertown: Eastgate Systems.

Crawford, Peter \& David Turton, Film as ethnography, Manchester: Manchester University Press.

Devereaux, Leslie \& Roger Hillman, 1995, Fields of Vision. Essays in Film Studies, Visual Anthropology and Photography, Berkeley \& London: University of California Press.

Edwards, Elizabeth (ed.), 1992, Anthropology and Photography 1860-1920, New Haven \& London: Yale University Press \& The Royal Anthropological Institute.

Edwards, Elizabeth, 2001, Raw Histories. Photography, Antbropology and Museums, Oxford: Berg.

Flaes, Robert and Douglas Harper (ed.), 1993, Eyes across the Water Two: essays on visual anthropology and sociology, Amsterdam: Het Spinhuis.

France, Claudine de (ed.), 1979, Pour une Anthropologie Visuelle, col. Cahiers de l'Homme, Paris: Mouton \& École des Hautes Études en Sciences Sociales.

Francês, 1995, Imagens do Mundo. Mostra de Cinema Etnográfico, Lisbon: CEAS, CEMRI and IFP.

Hastrup, Kirsten, 1992, ‘Anthropological Visions: some notes on visual and textual authority, in Crawford, P. I. \& David Turton, Film as ethnography, Manchester: Manchester University Press.

Hirsch, Marianne, 1997, Family Frames: Photography, Narrative, and Postmemory, Cambridge, Massachusetts: Harvard University Press.

Hockings, Paul (ed.), 1995, Principles of Visual Antbropology, Berlin \& New York: Mouton de Gruyter.

Kunt, Erno, 1993, 'Approaches in Photo Anthropology - A Case Study from Hungary' in Eyes across the Water Two: Essays on Visual Anthropology and Sociology, Flaes, Robert and Douglas Harper (ed.), Amsterdam: Het Spinhuis. 
Landau, Paul \& Deborah D. Kaspin (ed.), 2002, Images and Empires. Visuality in colonial and postcolonial Africa, Berkeley and Los Angeles: University of California Press.

Mead, Margaret, 1995, 'Visual Anthropology in a Discipline of Words' in Hockings, Paul (ed.), Principles of Visual Anthropology, Berlin \& New York: Mouton de Gruyter.

Piault, Marc-Henri, 1991, 'Cinema Ethnographique' in Dictionnaire de l'Ethnologie de l'Anthropologie, ed. P. Bonte and M. Izard, Paris: PUF, pages 148-151.

Pink, Sarah, 2001, Doing Visual Ethnography, London: Sage.

Pink, Sarah, 2006, The Future of V isual Anthropology. Engaging the Senses, London: Routledge.

Ribeiro, José da Silva, 2004, Antropologia Visual. Da minúcia do olhar ao olhar distanciado, Lisbon: Edições Afrontamento.

Ribeiro, José da Silva and Sérgio Bairon, 2007, Antropologia Visual e Hipermédia, CD-Rom, Porto: Universidade Aberta.

Rouch, Jean, 1995, 'Os Pais Fundadores' in Imagens do Mundo. Mostra de Cinema Etnográfico Francês, Lisbon: CEAS, CEMRI and IFP.

Ryan, James R., 1997, Picturing Empire. Photography and the Visualization of the British Empire, London: Reaktion Books.

Sontag, Susan, 1983 (1973), Sur la photographie, Paris: Seuil.

Sperber, Dan, 1982, Le Savoir des Anthropologues, Paris: Hermann.

Stoller, Paul, 1992, The Cinematic Griot. The ethnography of Jean Rouch, Chicago: The University of Chicago Press.

Taussig, Michael, 1993, Mimesis and Alterity: A Particular History of the Senses, New York: Routledge. 